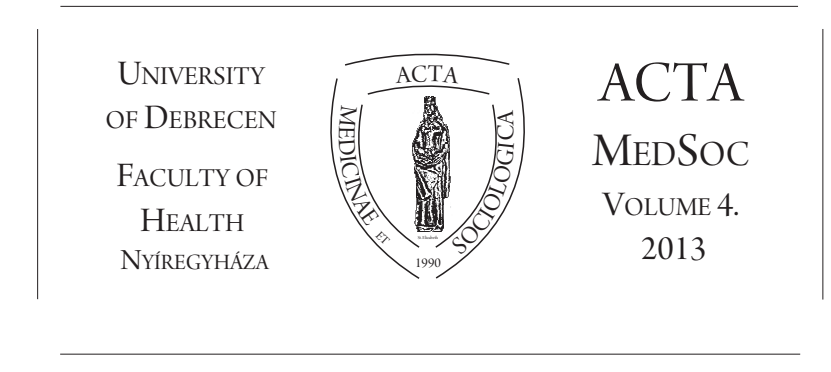

\title{
A francia szociális gazdaság, és annak rövid összehasonlítása a magyar szociális gazdasággal
}

\author{
Primuszné Sára Réka
}

DE-EK SOWOSEC

DOI: $10.19055 / \mathrm{ams} .2013 .4 / 8-9 / 10$

A szociális gazdaság olyan gazdasági tevékenységeket egyesít, melyek keretén belül különbözô közösségek, a teljesség igénye nélkül sorolva szövetkezetek, kölcsönös biztosítóegyesületek, és egyesületek jöttek létre.

Több érték mentén csoportosítható a szociális gazdaság tevékenységeinek köre, melyben a legfontosabb inspiráló elv a szolidaritás elve. E szerint a közös érdek előbbre való, mint az egyéni, illetve a döntések meghozatala demokratikusan kell, történjen (egy személy egy szavazat), mely során minden tag ugyanolyan jogokkal rendelkezik.

\section{A szociális gazdaság története Franciaországban}

A francia egyesülési tradíció sokkal mélyebben gyökerezik, mint minden egyéb, a szociális gazdaságról szóló legújabb kori törekvés akár ott, akár egész Európában. Az egyesületiség gyökerei tehát nem csupán a civil és szolidaritás-alapú gazdaság egy projektje, hanem a kooperatív szocializmus tradíciójának az egyik központi fontosságú megjelenési módja, mely mindenek előtt a demokratikus indíttatású republikánus mozgalomhoz kötődik.

Még a Francia Forradalom elótti időkben, 1780-as években számos egyesülés alapult a testvériség és egyenlőség eszméjén alapulva, a Felvilágosodás szellemében. 
Ezek a mozgalmak alapozták meg a forradalom tömegbázisát, 1793-ban akadémiák és nôi egyesületek, 1795-ben klubok alakultak. 1791-ben még tiltott volt minden gazdasági és politikai célú egyesülés, mely helyzetre a változást az Allard és Chapellier Törvények elfogadása hozott valamiféle megoldást. Ennek a témának a valódi kifejtése, egyetemes jogosultsággá tétele azonban az Alkotmányozó Nemzetgyưlés által összeállított, és elfogadott Emberi Jogok Nyilatkozatával érkezett.

A XIX. század első felében az egyesülések különbözó mozgalmak hatására alakultak meg, elsósorban munkások egyesületeiként, melyek egyúttal politikai célokat is magul elé tưztek. Fontos, kimondott céljuk volt a kölcsönös szolidaritás biztosítása tagjaik felé. A szakképzett munkások által alapított egyesületek kezdték aláásni a korábbi testületi múködéseket, egyre határozottabban a szekularizáció és a demokrácia elkötelezett szószólóivá váltak.

1815 és 1848 között Leraux és Tristan fogalmazták meg legmarkánsabban kritikáikat a poszt-korporatista múködések ellen, szorgalmazva egy ún. Munkaunió, azaz egy "munkaszakszervezet" felállítását. Ennek kialakítása a testvériség érzésére, és a szimpátiára épített, kölcsönös segítségnyújtáson alapult, minden dolgozó taggá válhatott, és hozzájárulhatott a vezetéshez.

1831-ben a Buchez nevével fémjelzett mozgalom hatására az egyesülés szélesebb jelentésú formája is megjelenhetett. Tágabban vett értelmet nyert az egyesülés azáltal, hogy saját maga is a szabadság szimbólumává vált. Ebben az értelmezésben olyan kollektív eszköz az egyesülés, mely egyenlő jogokat és kötelességeket ad tagjainak, munkásai között a versengést megszünteti, s melyben a benne dolgozók munkaeszközeiket és erejüket is "megosztják" egymással.

A nemzetközi téren zajló párhuzamos események között jelentôsként említhető 1844-ben, az Angliában létrehozott az "Egyenlóség Úttörôi" csoportosulás, illetőleg az 1847-ben Friedrich Wilhelm Raiffeisen által Németországban létrehozott szövetkezeti pékség.

1848-ra Franciaországban már nagyon sok egyesülésról tudunk. Univerzalitást nyert az intézmény abban az értelemben, hogy magát az államot is politikai egyesülés irányította. E gondolatiság vezette a törekvést, hogy ennek példájára a gazdaságot is egyesülési formában irányítsák: ezt képezte le a dupla jelentésû demokratikus és szociális köztársaság ideája. Minden erre törekvő szervezôdést két fontos jellemzô határozott meg: a világi vagy vallásos önkéntes indíttatású tagság, illetôleg a minden téren demokratikus társadalom eszméjének megtartása, a politikai indíttatású tartalom, mint alapvetô indíttatás.

A XIX. század második felében az egyesülések ügye a jogi szabályozás periódusába került. Hosszú évek huzavonái után a "szociális gazdaság szervezetei" címke került a szervezetekre. E definíció lényege, hogy a szociális gazdaság minden szervezeti formájában, legyen az szövetkezet, kölcsönös biztosítóegylet vagy egyesület, közös pont a korlátozott profitra való törekvés. A század végére az elóbbi mozgásoktól 
függetlenül újra fölmerült a szolidaritás eszmeisége, mely nyomán az egyéni jogokat és az állam felelősség kérdését igyekeztek összeegyeztetni (politikusok, jogászok és szociológusok, mint Bourgeois, Durkheim, Duguit vagy Bouglé).

A XX. század elsó 60 évében az egyesülések létrejötte természetes társadalmi reakció volt a gazdasági piacrobbanásra, s ez alapjaiban meghatározta a késóbbi állami beavatkozások útját is. A szociális tematika a piacgazdaság múködése nyomán létrejött társadalmi problémák enyhítésére alkotta meg a szociális törvényeket, beleértve a munkások jogait szabályzókat is.

E törvények közül első volt az 1901-es Törvény, mely végre elismerte az egyesülési jog, ezzel együtt a nonprofit egyesülések létezését az évszázados csatározások után. Az elismerés mellett ezzel lett vége a titkos társaságok, forradalmi klubok, és munkás-együttmúködések korának is.

A jóléti állam fejlődésével párhuzamosan a piacgazdaság és a jóléti állam szétválása a szociális gazdaságba tartozó szervezetek széttagolódását is elôsegítette. Az alábbiakban négy, nagyjából egységes csoportra leírása olvasható, melyek ettól az időszaktól kezdve a szociális gazdaság szervezeteit alkották Franciaországban.

Ezek egyik formája tehát a szövetkezet, mely elsôsorban azokban a szektorokban tudott hosszabb távon megélni, ahol a kapitalista érdekek nem bírnak erôsek lenni. E szerveződések önmegvalósítási törekvései azonban maximálisan elhomályosították a vállalkozások harcias politikai elképzeléseit. A jogi alapot a szövetkezetek múködéshez az az 1947-es törvény hozta meg, mely ötféle szövetkezetcsaládot állapított meg: felhasználói, banki, termelői, kooperatív vállalkozási és közös érdekeket támogató, vagy partnereket egyesítő szövetkezeteket. Emellett léteznek ma is olyan szövetkezetek, melyek termékek minôség-ellenôrzésére, a vidéki bankhitelek ellenôrzésére jöttek létre, vagy éppen az élelmiszer-elosztást segítik (pl. chéque-déjeuner).

A jóléti állam virágzása a kölcsönös biztosítóegyletek számára is fordulópontot jelentett. 1945-ben általános biztosítási rendszert alakított ki az állam, így a kölcsönös biztosítóegyletek csak kiegészítő szerepet játszhattak a továbbiakban. Franciaországban az intézményesülésnek ez a folyamata a Bismarck által elindított korporatista mintát hozta, minthogy a társadalombiztosítást összekötötte a munkajövedelem meglétével.

Jelenleg is múködnek a kölcsönös biztosítóegyletek a baleseti károk esetén, illetőleg a gépjármú-biztosítások területén.

A korporatista típusú jóléti állam berendezkedése Franciaországban több helyet hagyott a harmadik egyesülési formának, az egyesületek múködésének. Az egyesületek már korábban beléptek múködésükkel a szociális kérdések addig feltérképezetlen területeire. Az állam jó gondviselőként a törvénykezési szabályozás és 
finanszírozás útján irányíthatja az egyesületek életét, eszközül ehhez a szükséges anyagi forrásokat biztosítja. Ezek a szabályozások vezettek el a nagy, nemzeti föderációk létrejöttéhez is mind állami, mind vallási területen. Az egyesületek nagy számban múködnek a szociális szolgáltatásban, ennek valódi következménye kritikaként is megfogalmazható: erôs centralizációt hozott mindez magával, illetőleg az államtól való pénzügyi és jogi függóségüket.

Az egyesületek társadalmi dinamikában elfoglalt helyük alapján juthatnak valódi elismertséghez. Széleskörú múködési területükre álljon itt pár példa: otthoni segítségnyújtás, alternatív kórházi ellátás, ellátás fogyatékkal élő személyek számára, üdülőfalvak, közösségi központok, szakképzéssel foglalkozók, illetőleg olyan egyesületek, melyek a gazdasági tevékenységük révén vállalkoznak, stb.

A negyedik említésre alkalmas csoport a szociális gazdaság múködési formájában az alapítvány. Az 1987-es törvényi szabályozás szerint ez az a forma, melyben szabályozottan folyhat áruk, jogok, források továbbadása a köz érdekeinek és a nonprofit múködés követelményeinek megfelelően.

Hosszú távon a folyamatok oda vezettek, hogy az egyesülések a jogkövetô múködésre és a technikai irányításra helyezett hangsúlyaik okán nagyrészt elveszítették a közérdekre ható törekvéseiket. Ezen túl nehéz meghatározni a közös pontokat a szociális gazdaság egyes szereplôi között, mert míg például a szövetkezetek magukat piacorientált vállalkozásokként határozzák meg, addig az egyesületek megmaradtak a szociális területen betöltött szerepüknél.

Az 1960-as évek végére a francia szociális gazdaság fejlődésében fontos pont volt a jogi felismertetése a különböző múködési formáknak, mely egyúttal a szelekciót is elindította a már létező kezdeményezések között - létrejött a szervezetek intézményesülése. Emellett a szövetkezeti modell a szociális gazdaság standardjává vált, ezzel nagyrészt teljesen figyelmen kívül hagyva a korábbi fejlődés előnyös vonásait, azaz a többféle múködési forma jótékony, és fejlődést generáló voltát, illetőleg a gazdaság nem-piaci ágazatainak múködési formáit. A szociális gazdaság fejlődési korlátai közé számít az a közvetett haszonelvüségi változás az idôk során, ahogyan a múködés "érdeklődés hiányában" depriválódik a szervezett múködés igényei okán (azaz legyen minden minél kevésbé összetett, a magasztos célok nem szükségszerúen kell, hogy megjelenjenek a valódi élet valódi múködéseiben). Mindezek kapcsán fontos kritika az is, ahogyan az egyszerúsödés folyamata során a szélesebb társadalmi szerepük tekintetében e vállalkozásoknak elveszítik a kollektív cselekvő szerepkörét, mely a késôbbi (szak)politikai hatékonyságuk esélyét is elveszi.

További kritikája még a szociális gazdaság elméletének, hogy nem képes elfelejteni azt az alapállást, miszerint a modern gazdaság egyenlô a piaccal. E gondolatmenetben teljesen elfelejtődik, hogy míg a piac elsósorban gazdasági fogalmat jelöl, addig a szociális állam által végzett redisztribúció tisztán kisegítő funkciót lát el. 
E gondolatmenet következtében rendszerint a szolidaritás élő dimenziója felejtődik ki a gondolkodásból.

Mindezek ellenére a szociális gazdaság azon intézményi dimenziója továbbra is megmarad, miszerint a múködés keretében kollektív cselekvés zajlik, mely dimenzió maga igazolja a szociális gazdaság létjogosultságát minden jogosan megfogalmazott kritika ellenére is.

A XX. század utolsó évtizedeiben a több világméretú jelenség hatásával szembesült a szociális gazdaság szektora is Franciaországban. A szektor saját fejlődése, a társadalom általános elöregedése, a családi struktúrákban történt változások, illetóleg a globalizáció hatására létrejövő egyenlőtlenségek fémjelzik ezt az időszakot. A foglalkoztatás arányának változásai, illetőleg a fogyasztói magatartás általánossá válása mellett mozgalmak jöttek létre a mennyiségi helyett minőségi tartalomra való koncentrálás jegyében. Így léptek be új szereplóként a szociális gazdaság színterére a feminista vagy éppen környezetvédelmi indíttatású szervezetek. Új lendületet kapott a demokratikus törekvések érvényesítése is a szervezeteken keresztül. Olyan klienskört tudott elérni rugalmas szolgáltatásaival egyre inkább a szektor, mely a hagyományos, állami vagy kereskedelmi szolgáltatásokból kiszorultak, akik a foglalkoztatás világából estek ki, vagy akik alternatív megoldásokat kerestek szolgáltatás-igényeikhez.

2000-ben a témára nézve egyre erôsödő kormányzati figyelem végül regionális konzultációkat generált, illetőleg az 1901-es törvény centenáriumának megünneplését.

A jövô mindenképpen az a francia szociális gazdaság számára, hogy a szociális mozgalmak és a társadalmi szervek közötti kapcsolatokat javítva érjen el a szektor mélyebb elismerést és támogatást a társadalom részéról. A harmadik szektor francia megközelítése alapvetôen a szociális gazdaság oldaláról történik, az utóbbi harminc év története a sokféle szervezet jelenléte összesítésében a civil, illetóleg szolidaritás-alapú gazdasági perspektívát követi.

\section{A szociális gazdaság jellemzői, aktuális adatai Franciaország- ban}

A szociális és szolidáris gazdaság Franciaországban képviseli jelenleg a társadalmi innovátor szerepkörét. Erôs ágazatnak minôsül, amit az alábbi adatokkal is szeretnénk alátámasztani (forrás: www.socialinnovationeurope.eu ):

- a nemzeti foglalkoztatás $10 \%$-át adja,

- 4-5 \%-kal nôtt a foglalkoztatás aránya, amivel azt mutatja, hogy más ágazatokhoz képest a válság hatása kevésbé érződik rajta (pl. hagyományos vállalatok, közigazgatás) 
- 203.000 alkalmazottat foglalkoztat, 2,1 milliárd bevételt termel évente,

- a foglalkoztatottak aránya szerint a szektor munkavállalóinak 78 \%-a nonprofit egyesületnél, 13,8 \%-a szövetkezetben, 5,5 \%-a kölcsönös biztosítóegyletben, míg 2,7 \%-a alapítványnál áll alkalmazásban,

- 65-70 \%-a a szektorban foglalkoztatottaknak nő (kivéve a szövetkezeteket, ahol a nemek aránya egyenlő),

- a szervezetek kb. 20 \%-a foglalkoztat 50 vagy annál több alkalmazottat,

- a szektor forgalma a francia GDP kb. $12 \%$-át adja.

A francia szociális gazdaság alkalmazottainak 95 százaléka a szolgáltató szektorban dolgozik; 36,8 \% szociális tevékenységgel, 15,8 \% oktatással, 11,8 \% pénzügyi szolgáltatással, 7,7 \% egészségügyi szolgáltatással, 4,4 \% üzleti szolgáltatással, 3,8 \% sport- és szabadidős szolgáltatással foglalkozik.

A teljesség igénye nélkül adunk egy felsorolást a példával is alátámasztható sokrétûségrôl és innovációról, mely a szolgáltatások tevékenységi körét illeti: innovatív fogyasztás, élelmiszer-osztás, helyi ökológiai alapú élelmiszer termelése és disztribúciós hálózata, oktatás, alkalmazott-megosztás, foglalkoztatási tevékenységú szövetkezetek, helyi cserekereskedelmi rendszerek, generációközti interakciók, szociális innovátorok inkubátorai, internetes szomszédsági hálózatok, stb.

Nemzeti irodák, alapok és bankok - felismerve a szükséget - szintén csatlakoztak a szociális innovációs és vállalkozási programokhoz, azok finanszírozásának támogatására:

- AVISE - szociális vállalkozások nemzeti ügynöksége, alapítva 2002-ben,

- ANSA - az aktív szolidaritás nemzeti irodája, koncentrált figyelemmel az olyan szociális innovációra, mely a szegénység és társadalmi kirekesztés témakörében dolgozik,

- Caisse des Dépots, MACIF, MAIF, Credit Cooperatif, IDES, France Active bankok vagy kölcsönös biztosítóegyletek, melyek a szektor finanszírozásában vállalnak szerepet,

- regionális tanácsok - az elmúlt években sok program indításával támogatták a szektort,

- a Szociális és Szolidáris Gazdaság Kamarája - minden francia régióban létrejött szervezet, melyet egy nemzeti kamara irányít.

Sok olyan jövóbeli probléma látható azonban a jelenben, mellyel a francia szociális gazdaság területének hamarosan meg kell küzdenie, az alábbiakban ezekrôl adunk 
egy rövid áttekintést. A szektor korösszetétele szerint 2020-ig legalább 520.000 fó, azaz a szektor foglalkoztatottainak kb. 24 százaléka éri el a nyugdíjkorhatárt. A helyzet kezelési terve pedig még várat magára.

További szükséglet, mely folyamatos utánpótlást igényel, az az innovációs és üzleti igény, mely állandóan új módszerek fejlesztését és átvételét igényli.

Elmondható a szektorról továbbá, hogy óriási aránytalanság van a szektorbeli és a tradicionális fizetések között, az utóbbiak javára. A szektorban a foglalkoztatás csak 55 százalékában zajlik teljes munkaidőben.

\section{A francia szociális gazdaság vázlatos összehasonlítása a ma- gyar helyzettel}

A szövetkezeti szerveződés szerepel a korábbi magyar történelemben. A társadalmi innováció legújabb kori története az mégis, amirôl a következókben a franciaországi helyzettel szembeállítva rövid összehasonlító értékelést adunk a következőben.

1990-es évek elejétól kezdve beszélhetünk nonprofit szektorról Magyarországon, mely az elôzó évtized egyre láthatóbb társadalmi problémáival került szembe a rendszerváltást követően.

Akkor is, és azóta is jelentôs tisztán látást igényel a sok tekintetben meg nem oldott helyzet, minthogy a társadalmi változásokra adandó válaszok, struktúrák mindig is nyílt végúeknek kell maradniuk, a finanszírozási kiszámíthatatlansága okán nehezen elérhetô az az állapot, melyben a problémákra adott innovatív válaszok egyszerre kreatívak és fenntarthatók is. A szociális gazdaság vagy harmadik szektor szervezeti meghatározásai estében érdemes tehát kerülnünk például a túlságosan megszorító meghatározásokat.

A magyar társadalom problémái a politikai és gazdasági rendszerváltás átmenete okán igen mélyre hatók, és mélyen is gyökereznek. Ilyen a többgenerációs munkanélküliség, a lakhatási és oktatási szegregáció, a foglalkoztatás alacsony szintje, illetőleg az (etnikai) diszkrimináció történelmi öröksége. Strukturális probléma nálunk, mely szembeállítható a francia helyzettel, a finanszírozás súlyos megoldatlanságai: a támogatás-függôség, valamint a hiányos szociális beruházások fentrôl-lefelé való megközelítésen alapuló döntések, az önkéntes munka nyugat-európai értelemben vett nem elterjedt volta, stb.

Nálunk is problémát jelent a népesség elöregedése, a növekvő munkanélküliség. Komoly gondot jelent a nagy roma kisebbség társadalmi helyzete.

A magyar nonprofit szektorról elmondható, hogy 2010-ben 64.987 nonprofit szervezet volt bejegyezve, melynek 4 \%-a múködött nonprofit gazdasági társaságként. A nonprofit vállalkozások alapvetóen a hazai szolgáltatási szektorban aktívabb szereplők. Számos korábban állami cég, önkormányzat alapított nonprofit gazdasági társaságot, a kedvezóbb jogi és pénzügyi feltételek okán. 
A francia helyzethez hasonlóan a szektorban foglalkoztatottak száma és aránya dinamikusan nó, a hazai nonprofit szervezetekben 2010-ben számítottan 116.000 főállású foglalkoztatott dolgozott.

Az értékelések ismeretében elmondható, hogy társadalmi innováció is létezik Magyarországon, de nem túl széles körben. Ezek elsősorban a civil szervezetek múködéséhez, már létezô szociális szolgáltatásokhoz kapcsolódnak. Az önkéntesség is ugyanígy múködik: hiányos szakmai és szervezési háttérrel rendelkező foglalkoztatási ág, mely azonban az utóbbi időszakban egyre nagyobb figyelmet kap, egyre gyakoribbá válik. Mégis messze van attól, a Franciaországban kulturális háttérben gyökerezónek is mondható szokástól, mely szerint ez ott széles társadalmi rétegek életében múködô mindennapi tevékenységi forma.

Magyarországon létezik pár olyan szokatlannak mondható civil mozgalom, mely nem csoportosítható egyik szociális gazdaság eddig tárgyalt fogalmi rendszerébe sem. Ilyen például a Budapest Bike Maffia, mely egyszerre végez közösségszervezó munkát sportolni vágyó fiatalok felé, köti össze mindezt jótékonysági akciók végzése során - azzal együtt - annak népszerúsítésével, és múködik maximálisan önkéntes alapon.

A vállalati társadalmi felelősségvállalás is egyre ismertebb Magyarországon, ennek legintegránsabb múködési formája a középvállalati kategóriában figyelhetô meg.

Az Európai Regionális Fejlesztési Alap és a Kohéziós Alap az a két finanszírozási forrás, mely elérhetô a társadalmilag értékes vállalkozási ötletek beindításához, a TIOP és TÁMOP formájában. Franciaországtól eltérôen azonban itthon nagyon kevés alternatív finanszírozási lehetôség áll rendelkezésre a pályázati támogatáson kívül, mely elsôsorban az innovatív programok, szövetkezeti pályázati vállalások további múködtetésének óriási nehézségeiben mutatja hatását.

Ez a probléma tetten érhetô a szponzorációs és adományozási kultúra magyar területen érezhető hiányosságaiban, illetôleg a kormányzati, önkormányzati szektor nem elégséges támogatásában. A nem elégséges kitétel ebben az esetben azt jelenti, hogy a társadalmilag fontos gyakorlati érdekképviseletet és munkahelyeket teremtô szociális vállalkozások bármely formája minden területen egyre csekélyebb tervezetten múködő támogatáshoz jut. Az egyes, jelenleg sok munkával, de elérhetô forrásoktól való függés emellett rendkívül nagymértékú.

Mindazonáltal maradjon részrehajlás e dolgozatban is. Az a hallatlanul fontos meghatározója a szociális gazdaságnak, miszerint múködése demokratikus alapokon nyugszik, a résztvevôk önkéntes választásán alapul, és társadalmilag fontos területeken hoz be lemaradást, minden egyéb hátulütôt, múködtetési nehézséget és 
kritikát elviselhetôvé tesz. A szabadság, egyenlőség, testvériség (és egyben a szeretet) eszményi állapotát ugyanis csak akkor kezdjük hiányolni, amikor már nincs, tehát: örüljünk, ha van rá törekvés.

\section{Irodalomjegyzék}

- Philippe Chanial - Jean-Louis Laville: French civil society experiences: attempt to bridge the gap between political and economic dimensins, The third sector in Europe (ed. Adalbert Evers), Edgar 2005, p. 83-100

- Peter Herrmann: Sozialmanagement in Europa, Baden-Baden, Nomos, 2005.

- Johanna Bödege-wolf: Organisationen der Sozialwirtschaft, Baden-Baden, Nomos, 2010.

- A nonprofit (közhasznú) gazdasági társaságok szerepe a magyar nonprofit szektorban (in: Statisztikai Tükör VI. évf. 76. sz. 2012. október 3. KSH)

- Secours Populaire (SPF) www.secourspopulaire.fr

- Caritas France www.secours-catholique.asso.fr/une/index.htm

- UNIOPPS www.uniopps.asso.fr/cgi/index.plx

- Wikipedia francaise: LÉconomie Social http://fr.wikipedia.org/wiki/Économie_sociale

- Stefane Vincent: Social Innovation in France http://www.socialinnovationeurope.eu/node/1904

- Brigitta Jaksa: Social innovation in Hungary és Judith Hamburg: The Corvinus Perspective (in:

http://www.socialinnovationeurope.eu/node/1907 )

- A szociális gazdaság magyarországi helyzete http://www.szocialisgazdasag.hu/szocszovkuttanossz

- Wikipedia in English: The Solidarity Economy http://en.wikipedia.org/wiki/Solidarity_economy

- Wikipedia in English: The Social Economy http://en.wikipedia.org/wiki/Social_economy 
